\title{
OS DEUSES E OS MORTOS: MALDIÇÃO DOS DEUSES OU MALDIÇÃO DA HISTÓRIA?
}

\author{
Ismail Xavier \\ Universidade de São Paulo
}

\section{A decadência na zona do cacau}

O tema da decadência na representação da experiência de grandes familias ligadas à propriedade da terra eà monocultura ganhou relevo no cinema brasileiro do final dos anos 60, início dos 70. Os Herdeiros (Carlos Diegues, 1969) focaliza a crise dos barões do café; A Casa Assassinada (Saraceni, 1971) traz a crônica da decadência patriarcal no interior de Minas, e O Dragão da Maldade (Glauber Rocha, 1969) inclui a questão do declínio do mundo doméstico dos coronéis do sertão na representação dos conflitos já presentes em Deus e o Diabo. Em Os Deuses e os Mortos (1970), de Ruy Guerra, o discurso sobre um mundo em desintegração assume papel central na composição dramática. Esta focaliza os conflitos entre a tradição dos proprietários de terra e a intervenção dos comerciantes na zona do cacau, sul da Bahia, no período da Primeira República.

Este filme de Ruy Guerra traz o recuo no tempo típico ao filme histórico, mas seu horizonte é o de uma alegoria totalizante do sistema neo-colonial representado aí como um pesadelo, cenário onde estão em pauta aspectos da experiência humana que ultrapassam a questão da

\begin{tabular}{|l|l|l|l|l|}
\hline Ilha do Desterro & Florianópolis & $n^{\circ} 44$ & p.045-076 & jul./dez. 2003 \\
\hline
\end{tabular}


crise do cacau, pelos idos 1910-1920, e ensejam um laboratório dramático capaz de expor uma estrutura mais permanente de dominação, dentro da polaridade nacional/estrangeiro. Ao mesmo tempo, o filme traz em primeiro plano o debate sobre questões de identidade e interesses administrativos à distância. Uma dimensão antropológica ganha relevo em Os Deuses e os Mortos, cristalizada numa atenção às representações sincréticas do mundo rural brasileiro, com seu catolicismo rústico, seus traços de religião ameríndia e sua incorporação da cultura africana. Como acontece com freqüência na focalização do passado, o alvo maior deste filme é a discussão do presente, notadamente pela sugestão de semelhanças, recorrências, estruturas comuns de vivência a conectar os dois tempos. Como em outros filmes do mesmo período, há aqui um movimento de "revisão da história", sem dúvida deflagrado pelos cortes de 1964 e 1968, quando entrou em crise a teleologia de salvação que alimentava o Cinema Novo e redefiniu-se a forma da articulação entre mundo prático e fé religiosa. É o momento em que o problema da modernização reflexa passa a ser focalizado em suas dimensões mais sombrias ${ }^{1}$.

Dialogando de forma explícita com as alegorias de Glauber Rocha, o mundo de Ruy Guerra exibe uma organização do tempo que ressalta o peso dos fantasmas do passado no presente, numa incidência de mito e violência que não se desdobra, neste caso, em esperança revolucionária. Presente a história material, a crise no mundo do cacau se desenha a partir do cerco econômico externo, encarnado nas figuras típicas de banqueiros e comerciantes; por outro lado, presente a dimensão mítica das experiências, a crise passa também pela ação mágica do "forasteiro", agente enigmático que parece emergir do universo dos deuses e dos mortos para fazer com que a lógica da vingança escape ao controle dos coronéis, instalando um "fim de mundo" na rivalidade entre os Santana da Terra e os D’Água Limpa.

Movida pela ação deste agente que interfere na sucessão dos crimes de retaliação, a alegoria de Ruy Guerra representa lutas sociais vividas como autênticas "sagas de família" pelos seus protagonistas, 
encadeamentos de morte que a narração expõe sem, no entanto, ela própria se ater à forma da saga, pois seu interesse é emoldurar os conflitos, contextualizá-los, dispor dos acontecimentos como uma parábola sobre a ambição e o poder dentro de condições determinadas. Destaca, deste modo, o mundo de relações mágicas interno à cultura do cacau, o mundo da tradição local onde a família é princípio maior de organização política, econômica, religiosa; mas o contrapõe a um quadro mais amplo de relações, em particular a ordem econômica de dimensão planetária, o universo da mercadoria. Dado o seu objetivo de trabalhar um mundo "por dentro", expondo ações e mentalidades, e "por fora", expondo seus limites e seu encaixe numa ordem internacional, a narração opera aos saltos e nos coloca diante de figuras enigmáticas que requerem interpretação. Há, por outro lado, dado o imperativo de condensasão, situações bastante esquemáticas, pilares de uma pedagogia que disputa terreno com os rituais tingidos de vermelho que expressam um programa estético cuja tônica é a "experiência do choque". O resultado é uma combinação às vezes instigante, às vezes não tanto, de lição clara e opacidade radical. No meio do caminho, entre o conceitual-pedagógico e o dado imagético pertubador, ganham destaque as figuras que materializam o imaginário sugerido pelo título do filme. São encarnações e imagens "suspensas", presentes desde a seqüência de abertura, que deixam claro o quanto estamos penetrando um universo marcado pela morte, habitado por fantasmas, espécie de mundo de danação onde até a retórica persuasiva de um motorista de caminhão adquire uma tonalidade de advertência profética a anunciar a desgraça.

\section{A abertura, os deuses e os mortos, o forasteiro}

Um material pastoso da cor do cacau vai formando na tela formas abstratas à medida em que as bolhas estouram em sua superfície ativadas pela energia do processo de ebulição. Esta é a leitura (metonímica) da imagem sobre a qual desfilam os créditos de Os Deuses 
e os Mortos: temos de imediato a presença da fonte da riqueza num estágio de transformação alheio ao espaço de sua plantação e colheita, fora dos domínios dos Santana da Terra e dos D'Água Limpa, quando o cacau sofre já seu destino de matéria prima nas mãos de quem decide o seu valor como mercadoria. Pouco interessa aí a experiência social que lhe deu origem-o mundo da fazenda e dos coronéis, a cultura dos plantadores, os conflitos da gente viva, os deuses e os mortos.

Tal moldura inicial tem clara pertinência num filme interessado no aspecto implacável dos processos da economia política. Por outro lado, metaforicamente, a ebulição, afora sua conotação industrial, é imagem que transmite sensações, expondo um material em crise porque submetido a um excesso de energia, sua cor e movimento já rimando com o teor dos dramas. A figuração do calor remete ao próprio terreno da estória e, em particular, ecoa na primeira cena do filme, ainda banhada pelo clima da música da apresentação. A voz de Milton Nascimento se estende um pouco por cima da banda de imagem até que o motorista de um caminhão de retirantes assuma o comando. Este fala do Sol que endoidou, da terra quente, da seca, do inferno, da natureza em ebulição diante de homens estáticos. Não estamos ainda na terra do cacau mas num ponto de parada onde gente andarilha precisa decidir seu destino e está lá imobilizada numa paisagem rural. A natureza em si não traz a imagem de desolação afinada às palavras desse primeiro orador do filme, mas lá estão os espectros—os deuses e os mortos-a tornar estranha esta população de migrantes.

Em um plano geral, vemos ao fundo uma árvore com figuras humanas empoleiradas com ar de abutres a observar um desastre ecológico. O espaço da fala do motorista se preenche de figuras de teatro, um presépio dos santos populares mais afetos ao sincretismo (São Jorge, Santa Bárbara, Nossa Senhora da Conceição), espécie de assembléia dos mortos ao ouvir, sem maior atenção, a preleção cáustica do motorista que se dirige aos vivos, trabalhadores ainda dispostos a acreditar na terra verde do Sul onde há chuva e dinheiro fácil: "quem 
quiser vem que eu levo, o resto a gente acerta depois quando a verdade estiver nos olhos de todos".

Novo plano nos traz aquela população em movimento, ao lado de um posto da Rio-Bahia, em Milagres. A concha da Shell e os caminhões definem o tempo e o lugar em que se move este cortejo estranho de figuras andrajosas. Trata-se do mesmo lugar onde termina $O$ Dragão da Maldade, ponto de passagem entre o sertão e as terras da promissão e do progresso, fronteira entre dois mundos já visitada por Ruy Guerra desde Os Fuzis (também filmado nesta cidade em 1963/64). Tudo remete, de imediato, a um universo intertextual que põe em confronto três filmes que, nesta identidade de locação, figuram o tratamento da fronteira entre dois mundos, nesta confluência de retirantes, caminhões, agentes da repressão e sinais variados da experiência religiosa que o sertão traz consigo. Os Fuzis colocava em seu centro a confrontação dos retirantes (místicos famintos, com seus deuses, sua mentalidade "arcaica") e dos citadinos (policiais protetores dos armazéns e choferes de caminhão que transportavam as mercadorias para outros cantos). Toda a cena se desenvolvia em Milagres, e Ruy Guerra demarcava muito bem as áreas de conflito, deslocando o centro do drama para a esfera dos que vieram da cidade. Os soldados chegavam para proteger a propriedade e não estabeleciam contato com a massa faminta, ameaçadora, sob observação. Traziam um único interesse: cumprir o dever profissional. Quem precipitava o conflito final era um chofer de caminhão (ex-soldado) cujo protesto isolado gerava a troca de tiros e sua própria morte. A catarse da luta ecoava no universo dos retirantes que matavam um boi, considerado santo, para comer. O dado essencial, no entanto, era o fechamento do ciclo de intervenção dos soldados que tinham vindo para manter separadas a esfera do povo e a do proprietário das mercadorias. Missão cumprida, a invasão não se consumava; o povo e a religião permaneciam em seus lugares, os impasses adiados neste confronto entre o arcaico e o moderno. Em Dragão da Maldade, a situação de base de Os Fuzis-massa retirante e proprietário ameaçado—é retomada, agora fazendo intervir as matrizes do mito 
popular no caminho das personagens: a separação entre as esferas se quebra, como sempre em Glauber. A ação rebelde vem de um cangaceiro que se põe como porta-voz da massa e invoca toda uma metafísica; o agente repressor vem, igualmente, da cidade mas se trata da figura mítica de Antônio das Mortes, que pertence mesmo ao sertão. Dotado das mesmas referências no mundo dos deuses, ele se converte à causa dos que têm fome, intervindo no conflito de forma distinta à dos soldados do filme de Ruy Guerra. A situação dramática de base, que desta vez inclui o massacre, termina por se tornar um pretexto para a pedagogia que procura a criação de uma "frente revolucionária" contra os donos do poder.

Os Deuses e os Mortos, ao se reapropriar desta passagem em Milagres, cita o plano do filme de Glauber-Antônio das Mortes ao se retirar sozinho, junto à estrada e ao posto de gasolina-e instala aí o seu cortejo dos retirantes, os vivos e os fantasmas que os acompanham, num cenário da Milagres de 1970, longe da Primeira República do coronelismo, longe do apogeu do cacau na sucessão dos ciclos agroexportadores. Um diálogo sem cerimônias nos informa que os retirantes que observamos, nesta abertura do filme, ainda se dirigem para a zona do cacau. Antes do recuo no tempo, antes de começar propriamente o relato, uma última cena traz os motoristas, no banheiro da parada, a comentar o destino de sua "cargas" —o Sul ou o cacau. E o ambiente prosaico desta conversa exibe seu contraste com as conotações bíblicas de falas e imagens anteriores; a migração desce de sua conotação peregrina para a sua verdade de mão-de-obra imersa na pobreza, realidade dos anos 60-70 que dá continuidade a uma tradição secular que já coleciona seus espectros. Evoca-se, de saída, a permanência de um dado estrutural - a mobilidade gerada pela carência se mantém e se põe em cena o imaginário de céu, inferno e peregrinação que lhe é correlato. Mas o presente é, em Os Deuses e os Mortos, um elemento quase extra-diegético, prólogo cronologicamente distante do palco efetivo das ações. 
Definidos os traços de permanência, o elo de ligação entre o presente e o passado é uma imagem bastante ambígua: antes da primeira cena no mundo dos Santana da Terra e dos D'Água Limpa, temos o plano rápido onde vemos os espectros, estas figuras que atravessam o tempo, agachados de costas para a câmara, formando um círculo, seminus ou envoltos em trajes rotos e empoeirados como mendigos, escravos ou penitentes. A tais figuras, associamos a dor, o sofrimento, a mortificação, não propriamente a condição olímpica de deuses. Sua presença imprime uma tonalidade de impureza ao espaço da cena e sugere relações que só se tornam menos enigmáticas mais adiante, na medida em que cadáveres seminus e tinta vermelha vão ganhando destaque nesta população sui generis dos campos de cacau, das fazendas e das ruínas da cidade, como que sinalizando a dívida de sangue aí acumulada. Em tudo, se expressa neste espaço uma condição de crise permanente avessa ao estado de graça, mundo sem descanso e de questões não resolvidas. Os deuses e os mortos, a meio caminho entre o céu e a terra, impõem, enfim, uma "carga" feita de memória e cobrança. Sacralizam, embora com sinal negativo, o terreno da história, inscrevendo o fluxo da matéria numa outra ordem de coisas onde a lei é repetição e cada ação paradigmática² .

Após este plano de transição dominado pelos espectros, chegamos à terra do cacau. Em plano geral, vemos dois jagunços a examinar os papéis de um padre que acabaram de assassinar. O cadáver está apoiado numa árvore e os jagunços examinam os escritos encontrados em sua bagagem: um ensaio sobre economia falando de fatos das primeira décadas do século, frases militantes do tipo "a guerra é justa quando necessária, pias as armas quando a esperança está nas armas", que bem poderiam vir de um padre guerrilheiro dos anos 60. A vitória é interrompida pelo aparecimento, ao longe e na linha dos trilhos de uma via férrea, de alguém não reconhecível. O forasteiro vem a pé, amarrado com as mãos às costas, e compõe uma imagem que desperta a curiosidade e, ao mesmo tempo, um certo instinto de caça nos homens armados. Um deles não resiste ao esporte de tomá-lo como alvo (tal 
como acontece na aposta de tiro ao alvo dos soldados, em Os Fuzis, que resulta na morte de um inocente anônimo). Embora não seja impossível imaginar imperativos de segurança para tal iniciativa, a conversa dos jagunços acentua o lado gratuito do gesto. Um deles comenta, com ironia, o toque de caridade, caso se pense o desconhecido mais morto do que vivo, vitimado de castigo e desejando paz. Os tiros se repetem mas a figura ao longe não dá sinal de ter sido atingida - continua a se aproximar sem temer as balas. Esperamos a sua queda mas, antes disto, a cena se interrompe.

A resposta é retardada pela introdução de um outro lance de violência, mostrado em único plano: a câmara está à beira de um rio, próxima de uma mulher que, com uma criança no colo, esconde o cadáver do marido (supomos) e prepara a canoa para a fuga; o movimento em panorânica permite ver, mais atrás, a casa da fazenda em chamas. Exposta a nova situação, voltamos à cena anterior, dentro de um procedimento comum em Os Deuses e os Mortos. O privilégio é dado ao plano-seqüência; minimiza-se a montagem dentro da cena e, quando esta se desdobra, faz-se uso de inserções paralelas que separam as várias fases de uma mesma ação. Entre os tiros e a queda do forasteiro, entre o campo e o contra/campo, o hiato do incêndio e da mulher em fuga (o que estabelece uma conexão entre estas personagens).

Quando retornamos ao ponto de origem, a câmara se põe junto ao forasteiro. Gira em torno de sua cabeça enquanto ele cai lentamente, em primeiro plano, o sangue escorrendo pela boca, até que seu rosto pouse na terra. Nossa proximidade permite captar o que parece ser um derradeiro delírio: "quero rei, quero rainha, quero palácio, quero engenho, quero cana, quero bagaço, quero pai, quero mãe, quero filho, quero o tampo da cumbuca do balaio...". Enquanto declama, nenhuma expressão de dor, apenas um sorriso contínuo a selar o enigma.

Com este sorriso e esta forte oração do desejo, se encerra o primeiro ciclo de impactos em Os Deuses e os Mortos. Fomos lançados no seu universo de violência e espectros, estando agora cheios de perguntas e já tomados por sua atmosfera. É o momento de algumas explicações. 
Estas vêm numa sucessão de planos-seqüência marcados pelos extraordinários movimentos de câmara-na-mão de Dib Luft. Vejamos o contexto das forças em confronto.

\section{Terra da promissão, terra maldita}

Reina uma certa paz no pátio da fazenda dos Santana da Terra, visto em plano geral, rapidamente, antes que a câmara, na varanda, gire para nos lançar no espaço da Casa Grande. No meio da sala, o Coronel, de galinha preta nas mãos, fala de economia e de guerra no diálogo com um banqueiro, observado pela sua mulher e Sereno, a mesma figura feminina que já vimos em fuga. $\mathrm{O}$ ambiente é amplo, rústico, de móveis pesados e paredes quase nuas; a câmara o descortina à medida em que acompanha o jogo de cena. Sob a proteção desta família, a mais tradicional entre as proprietárias da região, trabalhava o marido de Sereno e, como é devido, ela agora recebe o apoio do coronel para os funerais; no entanto, vê recusado o pedido de vingança imediata e sua exigência de um documento de posse de terra prometida, há muito, pelo Coronel. Este, por ora, diz: "cada coisa a seu tempo e à minha maneira". O patriarca dos Santana da Terra está mais preocupado com as palavras do banqueiro que ameaçou retirar seu apoio caso se prolongue a refrega com os D'Água Limpa: "Sereno não vale uma guerra".

A cena seguinte, no bordel da pequena cidade, nos dá notícias do estranho baleado. Uma janela deixa avistar a praça retangular, simétrica e nua, sem ninguém, como parece ser a regra; a câmara passeia pela grande sala do bordel e vislumbramos o forasteiro vivo, ainda com o estranho sorriso, sob os cuidados da dona da casa. Esta é dada a comentários filosóficos enquanto acompanha o vai e vêm das mulheres no preparo do cotidiano para a freguesia noturna; uma mulata se lava numa pequena banheira que combina com o visual do ambiente cheio de objetos, móveis estofados, tapete estampado, plantas, gaiolas com passarinhos, flores, um quadro com motivo religioso de cores fortes, 
papel de parede, inscrições, numa riqueza de elementos decorativos que contrasta, pela urbanidade kitsch, com a sobriedade da Casa Grande dos Santana da Terra e estabelece uma polaridade estilística que sinaliza a ordem de ocupação da região: da fazenda ascética ao arremedo de conforto citadino. Um visitante comenta as sete balas recebidas pelo forasteiro, sua diabólica sobrevivência. A dona da casa alude às violências que testemunhou pelo mundo afora, aos mortos e seus "rostos nus" que ainda guarda na memória: "em cada morto, escondido, havia sempre um gosto de ouro".

A frase de efeito "dá a deixa" e cortamos para uma das poucas ruas do povoado. Numa nova imagem, acentuam-se as relações sociais, o ritmo do mundo do cacau a que recuamos: um homem de terno branco e chapéu Panamá (identificado depois como Venâncio, o político da família D'Água Limpa), figura letárgica, sem vigor, é transportado por um conjunto de homens, também de terno branco, numa leiteira, até que a carga seja depositada no chão, junto ao que vale como calçada. Revelar de imediato o destino da personagem seria articular dois planos, dando fluência à ação. Há preferência, novamente, pelo retardo: 0 flash de um cadáver nú, baleado nas costas, caído na mata, se antecipa à cena no armazém dos D'Água Limpa onde Venâncio e seus parentes falarão da crise econômica no mesmo tom sentencioso já observado na fazenda dos Santana, mas os epítetos e os espaços a que ficam associados definem bem o lado mais citadino, comercial, de Urbano D'Água Limpa, sua menor tradição na posse da terra. No momento, a conversa dos D'Água Limpa mescla as duas ordens: a do comércio do cacau e a das lutas de família. O pai Urbano, os filhos eo Venâncio, que está chegando de Ilhéus sem ter obtido o empréstimo desejado, falam da queda dos preços do cacau na Bolsa de Londres, do aumento da produção na Costa do Ouro, da crise que se afigura para os proprietários brasileiros sufocados pelos intermediários ingleses. "O monstro está escancarando a goela”, diz o coronel Urbano D'Água Limpa, avaliando as oscilações de mercado com uma linguagem bíblica que é questionada pelo seu filho Valeriano - a figura cética da família. O coronel Urbano rechaça a 
objeção-"é olho por olho, dente por dente"—sobe descalço sobre a montanha de cacau seco no armazém, acentuando o tom ritual de sua fala que discorre sobre a crise comercial, as eleições regionais e sua luta com os Santana da Terra: "o inimigo tem mil caras".

Uma delas se define de imediato. Tem aspecto balofo e está instalado no bordel. Em plano frontal, o almofadinha pousa para a câmara e se apresenta-“"sou um homem de números". Sua figura e tudo o que a cerca-a prostituta agachada a seu lado, as cores e a decoração do ambiente, a melancia em suas mãos, os passarinhoscompõem uma alegoria: a do estrangeiro a negócios num país tropical. Como banqueiro, ele nos dá uma lição sobre o comércio mundial do cacau e se refere à principal casa exportadora a Whitaker \& Son.

A imobilidade deste último plano-seqüência contrasta com a inquietação da câmara nos planos anteriores, onde o próprio movimento do diálogo ou das "grandes sentenças" se refletia na exploração dos rostos e dos ambientes, com uma constante movimentação que transferia ao espectador um senso de instabilidade. O movimento do corpo e o das palavras dentro de espaços bem marcados trazia o peso da experiência passada e da relação com a natureza, pois todos na terra do cacau-dominantes e dominados-parecem se mover num mundo de relações em que o sensível e o inteligível ainda não chegaram àquela separação própria às abstrações citadinas. Nesse mundo de gestos solenes, a palavra assume um tom de palpabilidade que contrasta com a retórica dos números do banqueiro. A sucessão dos tableaux, com este contraste de estilo, é bem demarcada: cada cena define um ritual e uma pose característica. A não fluência de ação na passagem de plano a plano cria um efeito de compasso de espera que se cristaliza com nitidez na imagem que encerra a apresentação dos principais agentes: a praça exibe de novo a sua simetria, o seu ar deserto, tomada em plano geral; lentamente, nela se deslocam duas figuras que ainda não somos capazes de identificar, um branco com ar burguês de uma urbanidade muito composta face ao padrão local; outro negro, mais próximo da câmara, com ar de guarda-costas, de carabina em punho. 
No elenco dos agentes que compõem a trama, temos, então, dois tipos estranhos ao mundo dos Santanas da Terra e dos D'Água Limpa: o "alvo da caça" que sobrevive ao capricho do jagunço e esse tipo "estrangeiro" que atravessa a praça com seu guarda costas. Um vem a pé no leito da vida férrea e traz consigo o enigma da sobrevida e a máscara grotesca, monstruosa, nas feridas. Sete vezes—esteé seu nome, pois sete vezes foi baleado-é a figura suja, contaminada, que emerge como que da terra, trazendo no corpo as marcas de uma tradição local associada ao sangue, à lama. O outro é a figura limpa, de ínicio também enigmática, que não vemos se relacionando com os da cidade. É das poucas figuras que aparecem sem uma identificação pela palavra, se mantém à sombra, para só vir a primeiro plano no final, revelando-se o verdadeiro "homem dos números" associado ao mundo da organização e à eficácia do comércio. Ele não se mistura à violência das lutas de família nem parece interessado na mitologia da terra, esta em que Sete Vezes se envolve de corpo inteiro. Sua condição é de exterioridade, isenção, posso dizer superioridade, frente à engrenagem da vingança que, uma vez posta em movimento, cria uma atmosfera de apocalipse na terra do cacau. Um apocalipse para o qual não faltam profetas.

Os donos do poder falam de "fim de mundo" e sua retórica mescla fatores materiais e ordem metafísica, como se as vicissitudes da economia do cacau se encaixassem num tecido de atuação caprichosa da Providência e como se seus direitos estivessem apoiados em textos sagrados, legitimadores da tradição de nome e propriedade. Este alarme encontra confirmação na própria configuração da crise pois, à medida em que o filme avança, a violência parece sem freios e escapa, como nunca, do controle dos senhores. De um lado, é a pressão dos mecanismos de extorsão comercial, cujo foco é externo e faz os donos do cacau "sufocarem na própria riqueza"; de outro, é a crise interna que faz vir à tona toda a violência que, por baixo do mito da terra prometida, se acumulou na efetiva experiência histórica, dado o perfil predatório da ocupação da terra, a relação com a natureza e a exploração das levas de migrantes vindas do sertão. Sob a camada da tradição e do nome, há 
uma experiência de dor e violência acumulada que encontra agora seu tempo forte de ajustes de contas. Diante destas duas pressões, a fala dos senhores da terra parece cada vez mais ajustada a seu efetivo destino. Em outras palavras, o "foco metafísico" de Os Deuses e os Mortos é a própria narração, não as personagens. Estas, por seu lado, têm efetivamente sua queda por vaticínios, queda que encontra seu foco maior na vidente interpretada por Dina Sfat, mulher do povo que encarna a condição feminina, na terra do cacau, em seu limite.

As prostitutas do bordel e as mulheres da família Santana da Terra-a madrasta Soledade, a filha Jura-definem os polos antitéticos da estratificação social e da destinação feminina naquelas paragens. Elas compõem peças de lugar definido no processo de reposição de ordem: umas, objeto de posse no circuito da continuidade da estirpe, da legitimidade e da herança; outras, no circuito da vida presente, do prazer, da transgressão que garante o equilíbrio do sistema. Sereno, enquanto viúva de posseiro pobre, sem popriedade, sem nome de família, estaria destinada aos engodos do Coronel e à vida no bordel. Na avaliação do banqueiro, ela "não vale uma guerra" e, por conta dos Santana da Terra, sua degradação estaria inserida na ordem natural das coisas. No entanto, ela termina por ser uma figura de desequilíbrio, pois não espera a ação dos poderosos, recusando a passividade da mulher-objeto, protegida. Embora o bordel marque o seu roteiro, não a retém, pois ela se recompõe antes de cair na zona limítrofe em que a perda de tudo e da dor poderiam radicalizar um trajeto em direção à loucura, em direção à personagem de Dina Sfat. No jogo de espelhos da galeria feminina, esta, a vidente, encarna o ponto extremo de isolamento. Em verdade, seu movimento se dá em outra esfera, de onde observa com o olhar insólito de uma Cassandra do mundo do cacau, mediadora entre os vivos e os mortos. É o clima dos funerais que a introduz no filme.

Sereno matou Aurélio D’Água Limpa, vigando-se do massacre em sua casa. São dois, portanto, os enterros: o de seu marido e o de Aurélio, cada um conduzido por uma das familias em luta, os patriarcas à frente no passo lento pelas ruas. Destes cortejos paralelos, saltamos 
para os campos ao redor da cidade e lá encontramos a figura sombria a completar a atmosfera de luto. Sua gravidez, logo visível, não consegue romper a cadeia de associações ligadas à morte; sua movimentação, por longo tempo seguida pela câmara, nos traz de volta os espectros observados na abertura do filme. Eles observam um piquenique - 0 de Jura, a filha dos Santana da Terra-mas sua presença é apenas reconhecida pela vidente, em sua movimentação. Ela circula, observa lençol e comida, faz caretas para Jura (que não registra nenhum incômodo), provoca os fantasmas com acenos e cusparadas (estes também não reagem). Seus movimentos e atitudes a situam na esfera dos fantasmas que, em verdade, só ela é capaz de ver em todo o filme, partilhado conosco (câmara) tal acesso privilegiado. Isto define uma certa cumplicidade entre ela e a narração; faz com que alguns dados da crise sejam filtrados pelo seu olhar, único a merecer o corte em contracampo capaz de trazer imagens reveladoras. Na errância pelos campos, quando seu olhar fixo sugere o horror, as imagens seguintes materializam suas premonições: Valeriano D’Água Limpa, Urbano D'Água Limpa e o pai Santana da Terra estão todos mortos, caídos, o sangue a escorrer. Antecipado o destino dos chefes das clãs, ela se afasta em silêncio, como surgira, sendo substituída, na tela, pelo rosto de Sereno, no quarto do bordel, a figurar diante do espelho sua disposição à vingança.

A segunda intervenção da vidente ocorre quando o cenário está armado para que se confirme sua primeira profecia: a morte violenta do segundo filho dos D'Água Limpa, Valeriano. Sete Vezes o atrai para um encontro na cidade, numa casa abandonada, e dois longos planosseqüência constróem o ritual de agonia e morte. Entre estes dois planos, a figura da mulher a caminhar pelos campos vem se inserir e fazer ressoar suas imprecações. De um lado, há aquela repetição da estratégia de retardo, o encaixe de um outro espaço no meio da cena para quebrar a continuidade. De outro, tal inserção vem intensificar o teor dramático da execução de Valeriano: encarnando um princípio geral de vingança, a vidente desenha um apocalipse onde não haverá lugar para qualquer 
redenção, pois o mundo já foi julgado e condenado. Sua fala projeta sobre sua própria gravidez esta promessa de destruição geral; seu ódio e condenação da terra querem fazer do seu corpo a fonte do que é mortal - veneno, chumbo quente, pólvora, punhal—até que tudo seja uma coisa só, uma substância impura, podre, envenenada, sangue ruim onipresente, resíduo sem poder criador a perpetuar uma condição entrópica de morte absoluta.

A vidente está grávida de todos os venenos. Em contraponto, não há gravidez nos D'Água Limpa nem nos Santana da Terra. Parece não haver mais nada no mundo do cacau que se mostre fonte geradora de vida. A terra, geradora de riqueza, exibe na verdade uma fertilidade "maldita", diabólica. Promessa de felicidade e progresso, o cacau se revela fonte de desespero, e o desejo de "fim do mundo" da figura visionária encontra expressão no grupo formado pelos deuses e pelos mortos. Estes funcionam como um coro trágico cuja manifestação não endossa nem renega a maldição lançada, mas reconhece sua força ao assumir um tom aflito, de expressão de dor, que ressalta a pertinência deste desfile de pragas dentro de uma ordem maior que aponta, por trás de cada cadáver, o "gosto do cacau" (aqui, o cacau é ouro, como todos repetem desde Terras do Sem Fim, o romance de Jorge Amado com o qual filme de Ruy Guerra dialoga).

No encadeamento renovado da violência, o mundo do cacau vive um momento especial. Embalada por disputas já tradicionais, a crise vira surto irrefreável, ameaçando a ordem das famílias de desintegração total. Que seria a lógica desta desintegração e, dentro dela, que papel assumem os recém chegados ao mundo dos D'Água Limpa e dos Santana da Terra?

\section{A lei do sangue e a lei do ouro}

Os D’Água Limpa massacraram a família de Sereno e incendiaram sua fazenda. Sereno tomou a si a vingança e seduziu Aurélio, o filho de Urbano D'Água Limpa, atraindo-o para a morte no campo do cacau. 
Quando volta para a cidade, encontra Sete Vezes no bordel e anuncia: "Aurélio está morto". Urbano e Valeriano invadem o bordel, dão busca no local e perguntam para Sereno "quem matou?". Sete Vezes interrompe a cena e faz valer a sua presença estranha, desfiando uma narrativa que parece dotada de força hipnótica. Sob os olhares dos D'Água Limpa, imobilizados, de Sereno e da dona do bordel, ele fala de uma mulher "que alguns chamavam de Rosa, outros de Maria", cuja história em tudo se assemelha à de Sereno eà de muitas outras mulheres da terra: "...Um dia ele apareceu. Trabalhava a terra que era pequena e queria mulher. Falou e ela foi. Usou no monte, na "esteira" de sol e chuva, de ano a dia. Pariu duas vezes, um não viveu. O resto seguia. Chegou a colheita e eles também vieram. Tomaram o solo, tomaram os frutos, mataram tudo. Só a ela não, que mulher não se mata, e ela fugiu. Voltou à vida... Dizia que se chamava Rosa, às vezes Maria. Mas o certo dela, o que se sabia, era o que se via e o que se via assustava."

O tecido da trama, desde o início, sugeriu a sintonia entre Sereno e Sete Vezes. Agora, na cena com os D'Água Limpa, sua enunciação transforma a sentença "que não se mata" em lei da terra de que é porta-voz. Tal como ocorre com a vidente, seu carisma vem da imagem de flagelo, condição limite, que dissolve qualquer outra particularidade. Sete Vezes é o desconhecido "sem nome" cuja identidade se empalidece diante da contundência desta sobrevida de quem sofreu toda a violência possível e vê no mundo dos homens algo já sem segredos. Ele é eficaz em suas ingerências na ordem dos acontecimentos-lembra, por exemplo, um Antonio das Mortes-e deixa claro que sua força misteriosa está contra os D'Água Limpa. Sua intervenção não visa a devolver o que de direito pertenceria aos despossuídos; tem ambição própria (seu discurso inaugural não foi a suma do desejo?). E saberá estar no lugar certo quando se desencadear o aniquilamento recíproco dos senhores da terra. Se há uma tradição de violência, seu papel é acirrá-la, participar do circuito da vingança como uma emanação natural da terra, embora ninguém o conheça. Carrega um senso de legitimidade no desejo de posse, e vê chegada a hora de colher seu quinhão da riqueza 
como resultado de uma certa liturgia, de mesmo teor, no entanto mais eficaz do que o cerimonial das famílias. Sempre oracular na fala, é no cenário de um ritual de sangue que desenha para nós sua perspectiva.

Conversas, imprecações, enterros. Temos as coordenadas e o clima-Sete Vezes vem coroá-lo. Um porco do mato às costas, ele caminha em meio às casas pobres com um ar de caçador, homem próximo à natureza, cheio de cicatrizes. Quebrando a continuidade, novamente, saltamos para uma imagem de contraponto que traz a figura impoluta, de terno branco, do político dos D'Água Limpa sentado com todo o conforto a destilar sua retórica liberal; ele reclama das injustiças e da violência, exalta a sabedoria do povo que garantirá sua vitória nas próximas "eleições" (estamos na Primeira Republica). Voltamos a Sete Vezes, ou melhor, à imagem de uma poça barrenta onde ele mergulha as suas mãos, vistas em primeiro plano, e as retira amarelas para se dirigir ao porco do mato, amarrado junto ao solo. Ele esfaqueia o animal e se dirige à poça onde mergulha o bicho agonizante, de modo a que 0 sangue e a lama se misturem, o vermelho e o amarelo; eleva, em seguida, o animal para que o sangue the caia sobre o rosto ainda cheio de feridas. A música de Milton Nascimento assume em toda a cena uma conotação litúrgica e prepara o clima para a oração de Sete Vezes, iniciada após cumprir a primeira etapa da cerimônia: "Não tenho nome, o que pouco ou nada importa/andei nas aventuras do mundo, o que também não basta/Na cabala dos sete eu levei agora o chumbo que guardo na carne, não por vontade minha ou de Deus mas por vontade do mais forte que manda no fogo e na ferida/ Para quem traz as mãos nuas de ferro e sangue as idéias se perdem no som das palavras de protesto/ Sete Vezes me chamo até onde pode a memória e de sete caminhos vou chegar a destino que não aceito e não nego/Das misérias engoli a lama, esterco, urina/Guardei o corpo e o pensamento imaculado como uma vestal-agora basta/De meus dez dedos vou fazer outros caminhos de vitória/ As tatuagens de sangue que me deram os poderosos são os sinos de minha bandeira/Não quero saber o porque/Se a lei é o sangue e o jogo é o ouro, no sangue e no ouro vou buscar resposta." 
O contraste é muito nítido. De um lado, o ritual de Sete Vezes, seguido da oração que expressa ambição e promete violência porque tem assimilada a lição das coisas num mundo afastado de Deus e dominado pela lei do mais forte. De outro, a retórica vazia, o discurso cínico do político abastado que sabe que ali "a lei é o sangue e o jogo é o ouro" mas faz o teatro liberal e proclama o voto "secreto" como garantia contra a injustiça. Duas cadeias de pensamento: uma, de feição selvagem, feita com substâncias palpáveis, à mão, e com as marcas inscritas no próprio corpo; outra, de feição civilizada, feita com generalizações, idéias abstratas que mascaram a violência real. De certa forma, nesta oposição se figura a distância entre experiência histórica e aparato institucional que marca o país, notadamente no período local, que expressa um mundo prático e um imaginário próprios a uma formação pré-capitalista, e a lógica dos dominantes, atrelada à ordem moderna da mercadoria.

Posta a dualidade, a perspectiva de Ruy Guerra não é de adesão a um dos seus pólos - o da experiência imediata e seus encantamentos - como o mais "verdadeiro", pois o desdobramento da crise, dentro do filme, trabalha os limites, e não apenas as virtudes, deste saber sensível, terra a terra, personificado em Sete Vezes. Ele não é a expressão do concreto, da verdade inteira; é a manifestação imediata, brutal, de um estado de coisas cristalizado num corpo. No seu nível, tudo se põe ao alcance dos seus gestos e de sua voz. No entanto, considerada a mediação do contexto, é preciso examinar sua efetividade face às "abstrações" da política e das finanças, face à lei dos números associada, não à cabala que ele proclama, mas ao fluxo material da riqueza, este mundo desencantado do capital onde ele quer alcançar um lugar.

Há um eficácia inconteste na ação de Sete Vezes dentro da engrenagem da vingança. Protege Sereno, mata Valeriano e abre caminho para a guerra de extermínio entre as famílias. Ele encarna a peste que a vidente deseja, e sua aliança com as duas mulheres tem a benção dos "deuses e dos mortos" que parecem ter algo a cobrar dos patriarcas. Quando mata o filho dos D'Água Limpa, o espaço da casa 
abandonada está marcado pela presença simbólica de um cadáver de outras épocas, como que a abrigar memórias de outro tempo, de outras violências. Sete Vezes espera Valeriano; este, ao chegar, lhe diz: “...o que você tem com isto? que veio fazer aqui? pare de rir. Mandou me chamar para que? você tem cacau? não tem. Você tem terras? não tem. Tem familia? não tem. Tem nome?" Tudo isto é verdade, mas o tom de Sete Vezes é de cobrança como que tomando o D'Água Limpa como herdeiro que merece o tormento de sua presença, de sua fala enigmática, de sua oração do desejo. Entrega-lhe uma faca enigmática que Valeriano observa hipnotizado; conduz a cena. Há o corte para a aparição da vidente no campo e, quando voltamos à casa, lá estão Sereno e os Santana da Terra a assistir à morte do D'Água Limpa a navalhas, a observar seus gritos, sua correria e sua agonia em meio à lama e às galinhas no quintal. No fim do plano, a câmara na mão chega mais perto de Sete Vezes que, ao rosnar feito um bicho, estampa no rosto grotesco, ofegante, o êxtase da violência-vigança-desejo consumado.

Após esta cerimônia grotesca, tudo prepara a guerra sem vencedores. Na casa de Urbano, a fala solene invoca as escrituras em busca da legitimidade dos caminhos de morte a seguir. $\mathrm{Na}$ Casa Grande dos Santana, o discurso do velho—galinha preta na mão—é memória das glórias e dos direitos da familia, o agradecimento ao forasteiro pela ajuda e sua assimilação ao seio do império. Os deuses e os mortos habitam agora o centro da casa, sentam-se à mesa e tudo observam, imóveis como nos campos de cacau. $\mathrm{O}$ batuque africano pontua a fala do velho Santana e, num crescendo, cria uma atmosfera de transe que Jura, a herdeira, capta com toda a intensidade, caindo ao solo como que possessa, exibindo as convulsões de praxe. Tudo quer dar sinal da especialidade do momento, ebulição geral da terra (como em Terra em Transe). A convulsão coletiva, neste filme, tem sabor de efetivo apocalipse para os senhores da terra, sem que haja qualquer perspectiva de redenção para os dominados, em geral fora de cena. Quando os D’Água Limpa vão até o fim na matança com os Santana da Terra, a batalha se dá na cidade, o retângulo da praça servindo de palco. O povo 
vem ao centro da cena como jagunço na praça de guerra. E não sobra ninguém, à excessão de Urbano, para contar a história. Solitário, o patriarca dos D'Água Limpa chama pelo velho Santana, proclama a identidade dos rivais- "és o meu espelho e eu tua imagem"-e seu destino comum de morte. No entanto, o encontro dos coronéis não se dá neste momento. Será preciso a intervenção renovada de Sete Vezes. No campo do cacau, ele conduz o velho Santana para a morte nas mãos de Sereno e depois se instala na Casa Grande para esperar e matar Urbano. Limpo o terreno, ele toma posse do império.

Nos termos da "lei do sangue", a vitória do forasteiro as legitima perante os homens e mulheres da terra: foi conseguida com o risco do próprio sangue, conforme a tradição. Através dele, as pragas se cumpriram e a sociedade dos cacaueiros chegou à fronteira do suicídio coletivo. Terra arrasada, o cenário está pronto para que Sete Vezes, agora na Casa Grande dos Santana da Terra e "de costas para a morte" inicie seu reinado; tem a benção de Soledade, a amante de Santana, que lhe entrega Jura, a herdeira, como mulher. Ao final, no entanto, sua vitória neste plano "concreto" se revela a conquista de um grande vazio. Além das fronteiras de seu jogo, há leis mais fortes do que a tradição local, e mecanismos mais implacáveis do que o da vingança. Tudo pertence a quem, de mãos limpas, sem cicatrizes, apenas observou a luta. E fez seus cálculos "abstratos" dentro da lei da mercadoria, como homem de comércio que mal pisa na terra.

Salientei a montagem que inseria a retórica liberal do político na seqüência do sacrificio animal oficiado por Sete Vezes. Resta comentar o retorno do burguês bem composto e de seu guarda costas, as mesmas figuras observadas na praça vazia lá no inicio. São vistos agora como ouvintes entediados da fala dos grandes senhores da terra no limiar da batalha final, num paralelismo entre escritório comercial e praça de guerra que reforça o aspecto delirante do duelo entre os D'Água Limpa e os Santana da Terra.

O grande teatro está montado, mas o plano-seqüência só vai representar o clima de guerra, não suas ações. Os jagunços, de arma na 
mão, formam a disposição simétrica por todo o perímetro da praça retangular, sentados à espera do grande confronto. No centro da praça, de pé, Urbano D’Água Limpa, o comandante. A câmara "passa em revista" os jagunços imóveis, fazendo desfilar os rostos deste exército de pobres à espera da morte. Em meio à expectativa e o silêncio, nosso olhar salta para dentro de um armazém de cacau, onde o comerciante, sempre de terno branco e impecável, explica os mecanismos mais amplos do poder e da conjuntura nacional para o candidato dos D'Água Limpa. Ouvem-se os tiros da batalha. O comerciante comenta os desmandos locais, o colapso da economia e a intervenção federal inevitável. Pede que o candidato abandone as eleições: “...não é um conselho nem uma ameaça. Melhor do que ninguém o senhor sabe que a lei sem a força é uma abstração e que o dever de um líder é vencer. $\mathrm{O}$ lugar dos Urbano e dos Santana da Terra está sendo aberto nesta praça. Mas a vitória passa por esta sala. O senhor pode e deve escolher. Longe de mim, Dr. Venâncio, o heroismo aproxima o homem da morte." Dada a explicação e feita a proposta, voltamos à praça para deparar com os exércitos de jagunços dizimados e com Urbano a manifestar sua consciência trágica do caráter inelutável da mútua destruição, do colapso de uma época.

Na opção por este paralelismo praça/armazém/praça, temos a interpolação que nos sonega a imagem da luta de sangue para sobrepor a lição do capital. Os acontecimentos da praça correspondem a uma ordem segunda circunscrita por uma lei maior. Os lances da guerra não poderiam se representar com o dinamismo de um ação épica, pois o objetivo do filme é marcar sua "excentricidade" face ao movimento decisivo da riqueza. Se o velho Santana, num certo momento, diz que "os homens traçam os destinos de grandeza dentro do círculo estabelecido pelos deuses", a fala do comerciante poderia responder: 0 deus é o ouro e o destino quem circunscreve é o mercado. Se, no seu ritual, Sete Vezes proclama "no sangue e no ouro vou buscar resposta", seu percurso define muito claro o contraste entre o poder no terreno da lei do sangue e seu colapso diante da lei do ouro. Os paralelismos 
descritos integram o esquema maior pelo qual interagem, no filme, duas ordens dos acontecimentos: engrenagem da vingança e estratagemas do comércio. Nas duas passagens em que o paralelismo estabelece o contraste entre estas ordens, o que se tematiza é, numa delas, o aspecto pelo qual elas se estranham (cena do ritual de Sete Vezes e do discurso liberal a marcar a distância entre as duas). Na outra, o aspecto pelo qual elas, se estranhando, se encaixam-ordem do comércio circunscrevendo a ordem dos conflitos locais.

Os Deuses e os Mortos exibe suas oscilações ao articular esta estranheza e este encaixe entre os dois mundos. Há, em verdade, uma tensão curiosa entre o mergulho dentro da ordem social e metafísica das plantações de cacau entendida como unidade fechada, com coerência própria, e a constante referência às determinações externas que só mostram todo o seu peso ao final. O mundo mágico do carisma e o mundo desencantado da economia apresentam cada qual sua lógica e, no desenlace da conquista da terra, o segundo parece circunscrever o primeiro. Porém, quando tudo parece se encaminhar para a hegemonia da causalidade material e econômica, o desenlace entrega ao imaginário da região, aos deuses e aos mortos, a última palavra. Renova-se o enigma Sete Vezes.

\section{A crise sacrificial e a crise econômica}

A terra do cacau passa para outras mãos. O contexto geral da crise marca a formação da hegemonia dos comerciantes em detrimento dos produtores. É um momento chave de passagem, este que observamos ao longo do filme, no qual os estrategemas dos modernos catalisam o colapso da sociedade fechada e suas regras.Digo cataclisam porque não se pode eliminar a participação do passado, da própria tradição, nos fatos que inviabilizam esta sociedade por dentro como se ela perdesse a capacidade de ordenar a violência, domesticá-la, sucumbindo a uma desordem cuja lógica lembra a "crise sacrificial", este desencadear irrefreável da vingança que põe em xeque uma sociedade 
e sua ordem simbólica, tal como nos propõe René Girard em La Violence et le Sacré ${ }^{3}$. O ensaísta francês trabalha esta noção pensando em outro tipo de sociedade, sejam comunidades ditas "primitivas", seja a Grécia antiga. Mas o teor dos processos que analisa é exatamente este da crise instalada pela engrenagem da vingança quando a agressividade não mais se canaliza para a figura de um bode expiatório, condensação da culpabilidade geral, que receberia todo o fluxo da violência e, como figura pilar do sagrado e da ordem, garantiria a continuidade do grupo. No contexto do filme, os motivos da violência, o primado dos laços de sangue na esfera do poder, a rede de símbolos que legitima a hierarquia social, a dominação e as diferenças são todos elementos que não só permitem mas até convidam à aproximação. A dinâmica da desintegração observada no filme parece a desenhada por Girard em sua análise das relações entre violência e religião, entre gêneros de representação (como a tragédia) e a "crise sacrificial", quando a cadeia de retaliações desanda.

Na terra do cacau, tal cadeia é dado de estrutura, horizonte do colapso que, favorecido pelo influxo externo da pressão comercial, pode realizar todo o seu potencial de destruição sob o olhar cúmplice dos deuses e dos mortos. Na deflagração do processo, o que vemos é uma crise das diferenças: a identidade das famílias inimigas chega ao paroxismo; Sereno ultrapassa as barreiras e se põe como um sujeito da violência; Sete Vezes rompe as relações de mando e as separações de classe social; a fronteira entre os vivos e os mortos, entre o homem e a natureza, se dissolve, e a violência se desenha como lepra em todas as figuras, peste que contamina tudo; o fluxo do sangue se mostra em toda a sua impureza, mesclado à lama, não havendo lugar para um sacríficio purificador apto a cortar o fluxo e estabilizar a sociedade ${ }^{4}$.

Dentro deste quadro, a luta fratricida tem sua força maior de impulsão na figura que poderia desempenhar o papel de "duplo monstruoso" ${ }^{\prime \prime}$, cujo sacrifício poderia significar um caminho de purificação da violência que, dirigida a ele, cortaria a cadeia da vingança: Sete Vezes. Ele é o "desconhecido", sucedâneo de Édipo que 
descreve um outro percurso em direção ao poder e acaba assumindo um papel oposto ao do herói trágico no desencadear da desgraça: ele é o veneno mas não é o remédio, ao contrário do pharmakos grego. Chega como forasteiro e, ao longo do filme, vai configurando sua intimidade com tudo na terra, mas está longe do herói trágico ou mesmo do santo purificador, estando mais próximo de um Exu desestabilizador. A configuração do sagrado em Os Deuses e os Mortos é sincrética e, dentro dela, Sete Vezes condensa um princípio de vingança radical. No diálogo com Soledade, após a morte de Santana da Terra, ele é enfático: "Olhe o sol. Vê meu sangue, minhas feridas, meu lodo-é tudo teu. Te ofereço o que sou. Não minha vida que não tem valor, mas minha vontade de matar que não tem preço." E somente quando empolga o poder que assume o "agora sou" em sua plenitude. Senhor da casa Grande dos Santana da Terra, ele diz:

"é de costas para a morte que agora eu falo/antes não sabia o que buscava, agora sei o que sou; sou Santana, sou Urbano, sou Sol e sou Valu [Valeriano], sou Jura e sou Sereno. Viajei com a morte e me fiz dentro dela. Eu trazia a pele lisa, os olhos claros, os gestos dos vencidos e dos párias. Mas abri os dentes para a raiva e para a fome, e as mãos abri para a luta. Só e já morto como um Deus. Pisei no sujo, na lisonja, na intriga e, sem pena de mim mesmo nem dos outros, cobri os corredores de corpos cobertos. Onde pus o pé feri o solo. Gangrenei a paisagem com minha podridão e da podridão fiz minha grandeza...Agora sou e assumo."

Há dois movimentos em sua embriaguês: primeiro, a que instala a identidade entre o "ser pleno" e a vontade de poder, cume de onde ele pode voltar as costas para a morte e se pôr como um Eu que não precisa mais se definir como falta, "vontade de matar"; segundo, a que assume violência, morte e "podridão" como raízes necessárias desta plenitude 
só alcançada quando ele se sente portador da força natural, "só e já morto como um Deus".

Agente da vigança, Sete Vezes está no centro de uma alegoria que ressalta, à Shakespeare, o Grande Mecanismo do poder ${ }^{6}$. Como diz o velho Santana da Terra antes de morrer, "o homem que eu sou agora já não importa; o homem que vem é o que vale. E será sempre um Santana da Terra mesmo que mude de nome, que mate, que saqueie, que roube ou que chore. Porque o império é mais forte que o homem e fará dele o seu homem."

Temos então duas dimensões complementares do mesmo processo: a "crise sacrificial" (a engrenagem da vingança numa sociedade movida pela lei do sangue, sem força jurídica de Estado) e o Grande Mecanismo (a engrenagem de reposição do poder na vertigem do drama barroco: rei morto, rei posto). Isto não surpreende, pois é o próprio Girard quem sublinha uma certa dinâmica da "crise sacrificial" nas peças de Shakespeare, ou seja, no universo textual onde Jan Kott vê a ação do Grande Mecanismo. O ponto chave é que, nas duas dimensões, é Sete Vezes quem ocupa o lugar central: catalisa a crise sacrificial e encarna o Grande Mecanismo.

Posta esta complementaridade, é preciso considerar que há um terreno em que Sete Vezes perde, em função da intervenção externa (o deus-ex-machina do Capital), embora ele ganhe no mecanisno estrito dos ajustes de contas entre as famílias. Considerando o exposto, poderse-ia supor que a fala implacável do comerciante definiria, no filme, uma minimização da dimensão interna da crise; no entanto, se a reviravolta final esvazia a conquista do poder por Sete Vezes no mundo dos vivos, o epílogo vai repor sua figura no centro e celebrar sua "missão cumprida" no cenário dos deuses e dos mortos.

No terreno da ordem neo-colonial, a derrota de Sete Vezes se consuma quando ele, na sala maior da Casa Grande, já um Santana e patriarca legitimado pelas mulheres, faz seu discurso de posse com o "agora sou e assumo" mas se surpreende com uma visita, o burguês de terno branco, sentada à sua própria mesa. Este traz uma nova lição de 
economia política: em função das dívidas contraídas pelos Santana da Terra, o cacau pertence agora ao capital londrino que ele representa; os papéis em cima da mesa assim o dizem. Despossuído, Sete Vezes reitera a oração do início do filme-“"sou o rei, quero palácio, quero rainha, quero a cana,..." - e esboça o ataque armado de faca. Pequena pistola à mão, o burguês conclui: "mesmo que você me matasse não destruiria a cabeça; está fora do meu corpo...as lutas deixaram o Império vazio; você é dono de um império oco dentro de outro império maior." A camâra se aproxima do rosto de Sete Vezes e a força de sua reação muda deságua na imagem seguinte, quando saltamos para a imagem de um grande grupo de pessoas pobres que, à beira de um rio, parece viver em transe religioso, agora sim, cheio de lamúrias e com uma estridência que contrasta com as palavras do comerciante.

A vitória do mundo desencantado da ordem mercantil sobre o mundo do carisma e das relações de sangue define uma transferência de poder em que estamos longe da consumação de um princípio de justiça, reposição do equilíbrio social, tal como acontece no caso da derrota final de um tirano nas tragédias de Shakespeare. Não havia um "estado de graça" anterior na terra do cacau, Sete Vezes não destruiu nenhuma paz. Quando impôs a si mesmo a disciplina que reduziu o seu ser à "vontade de matar", apenas exacerbou a lógica da tradição, mantendo-se fiel à regra do jogo local. Desde modo, ele encarna uma crise da ordem que, de fato, se consuma na forma prevista por Girard; ou seja, tudo se precipita a partir do contato com um elemento pertubador externo - aqui, tal elemento é o capital londrino. Se a formulação de Girard tenta dar conta de um dos roteiros possíveis para situações marcadas pelo "choque de culturas", o filme de Ruy Guerra apresenta relações enigmáticas que, em larga medida, se ajustam a tal formulação. Resulta um drama que funciona como se acreditasse no encaixe entre uma teoria histórico-econômica do sistema neo-colonial e uma teoria antropológica da crise sacrificial, encaixe procurado como forma de alçancar uma representação totalizante da sociedade em foco. Procura, portanto, compor o drama respeitando a espessura própria do universo 
mágico-religioso dos protagonistas e sem abrir mão de uma visão capaz de expor também o contexto de modernização que ameaça tal universo. Nesta conveniência de referenciais, resta perguntar como se articulam ou se estranham as diversas perspectivas em confronto (a mágicoreligiosa e a político-econômica)?

Temos aqui o mesmo problema que o observador enfrenta ao fazer a leitura dos filmes de Glauber, caso de articulação entre mito e história que põe em seu centro a representação de surtos messiânicos no meio rural, surtos que a sociologia explica como típicos momentos em que a incidência de fatores estranhos à tradição local-no Brasil, frequentemente ligados à modernização na Primeira Republica—se desdobrou em crise de valores, no colapso de uma "visão do mundo", resolvida simbolicamente pela ação de figuras proféticas a anunciar o fim dos tempos, a produzir uma escatologia de salvação situada em outro plano face à realidade cotidiana ${ }^{7}$. Como observei, a noção de "crise sacrificial" chama a atenção para um outro caminho de resposta adotado por uma tradição local face a uma crise semelhante, caminho pelo qual, tal como vemos em Os Deuses e os Mortos, uma sociedade se autoaniquila sob pressão externa, resistindo de modo peculiar à adoção de um outro referencial, mesmo que mais poderoso técnica e economicamente.

Não se fala, neste filme, a respeito de tecnologia, desenvolvimento. A presença efetiva de elementos capazes de tornar claro o contraste entre sistemas de vida na região está ligada à urbanidade dos comerciantes e políticos, à distância entre norma jurídica nacionalrepublicana e a tradição local de violência. Se a mentalidade dos Santana da Terra e dos D'Água Limpa configura o célebre conservadorismo dos plantadores, a ausência de imagens do trabalho mostra o desinteresse de Ruy Guerra em tematizar o desdém dos patriarcas pela inovação tecnológica. Tal desdém é apontado pelos historiadores como um dado essencial da crise da sociedade cacaueira no Brasil, acoplado a um fenômeno que, este sim, o filme faz questão de destacar em sua abertura: a migração como produção da mão de obra farta e barata trazida dos 
sertões, abundância de braços que permitiu o apego a protocolos de rotina que acabou por condenar a cultura brasileira do cacau face à dinâmica internacional dos mercados.

Em os Deuses e os Mortos, diante desta ordem da economia política, Sete Vezes encarna o dinamismo interno da crise, a intervenção mágica dos deuses e dos mortos, tal como insinuado ao longo da trama e selado ao final, como veremos. Para Randal Johnson, sua vontade de poder e seu discurso final-“"onde pus o pé feri o solo, gangrenei a paisagem com a minha podridão e da podridão fiz minha grandeza" — têm algo de metáfora do capitalismo, afinidade que estaria corroborada por sua eficácia ${ }^{8}$. Minha leitura tem procurado acentuar, no entanto, a relação mágica de Sete Vezes com a natureza, sua oposição, digamos ontológica, à figura que o derrota ao final, figura cuja imagem, esta sim, é esquemática representação da burguesia. Sete Vezes tem traços nitidamente arcaicos, correlatos a outro modo de produção e ordem social. Não por acaso, ele perde naquela dimensão do embate que envolve os cálculos abstratos do capital. Não por acaso, o epílogo vem justamente reconhecer sua aliança com uma dimensão telúrica, mágica, presente no pesadelo que assola a região do cacau—a tradição também quis a morte dos Santana da Terra e dos D'Água Limpa.

Na cena final, Sete Vezes surge limpo, de terno branco igual ao dos Santana da Terra, galinha preta nas mãos. Como um patriarca, vem à frente de um cortejo, seguido de Soledade e Jura. Lá estão também os deuses e os mortos já observados ao longo do filme, ora estáticos, ora andarilhos, sempre, porém, preservando a separação com o mundo dos vivos. O cortejo se aproxima de um riacho, cuja água amarela, tingida pelo barro reitera a ausência de algo puro, cristalino, na terra do cacau, sempre permeada de lodo a embaralhar as coisas. À beira do riacho, Sete Vezes se aproxima um pouco mais da câmara e, de repente, parece dominado por uma convulsão. Rosna como um bicho, baba sangue, entra em agonia sacudido por uma crise interna. Ao cair, segura a terra com força, lembrando Galdino, a encarnação da violência e da ambição em O Cangaceiro de Lima Barreto, "força telúrica" condenada pelo 
tempo, como ele próprio. Aqui, porém, trata-se de uma morte celebrada, que insere a personagem em novo circuito, pois não é propriamente uma derrota - esta se deu em outro plano. Sete Vezes se esvaindo agora em sangue é pagamento de dívida, ou fechamento de uma fenda que se abriu no começo do filme. Missão cumprida, é chegado o momento de ele ser resgatado pelos pares, encerrando o ciclo de sua "sobrevida" não foi ele mesmo quem nos disse que abriu os dentes para a raiva e as mãos para a luta quando "só e já morto como um deus"? Agora caído, enquanto Jura se dirige ao riacho para iniciar a canção final, ele é recolhido pelos deuses e pelos mortos que o carregam até o cortejo perder-se na mata. Ficamos com Jura, no riacho, e ouvimos $A$ Canhoneira de Milton Nascimento.

Esta canção fala de "violência e tristeza", tematiza pela última vez a questão colonial, o espaço da derrota de Sete Vezes: o paradigma da canção é a pirataria inglesa, a diplomacia dos canhões, o saque direto que antecedeu as manobras comerciais; de modo solene e irônico, presta homenagem à máscara de melancolia de seus agentes, a fome e a "tristeza indefesa" do "capitão calado, o que leva o ouro-cacau" desta mata". No final da canção, nos afastamos da melancolia do império maior que absorve, além mar, a riqueza; e mergulhamos de vez no mundo dos fantasmas que se desenham como almas penadas a repetir o ciclo das dores da terra. Há um corte que nos afasta do rio, de Jura, e nos leva à mata onde reencontramos a ordem simbólica do mundo do cacau. Os deuses e os mortos formam um círculo em torno de Sete Vezes; este nu, amarrado, está caído de cara no chão, como um feto de bruços, na mesma posição em que o vimos lá no início entre os trilhos da estrada de ferro, caçado pelos jagunços. Fecha-se o círculo da morte adiada. E o jogo paradigmático da repetição se projeta na disposição dos fantasmas de pé agora em torno dele como no primeiro círculo em que, costas voltadas para a câmara, as figuras andrajosas não deixavam ver o centro agora preenchido pelo corpo do protagonista (me refiro ao plano de transição lá no começo do filme). No final, Sete Vezes vem ocupar uma posição que lhe parecia reservada nesse purgatório onde se movem os 
espectros, marcando a natureza especial de sua tarefa cujo sentido, no entanto, é difícil precisar. Se o seu carisma era sugestivo, este final confirma a tonalidade de "missão" dada a seu percurso. No entanto, devemos reconhecer que muita coisa permanece enigmática nesta ordem maior dentro da qual a crise orquestrada pelos deuses e pelos mortos faz sentido. O filme mobiliza uma diversidade de sistemas simbólicos que, em verdade, não estão articulados para especificar, no plano metafísico, os termos desta punição das famílias para além de uma alusão a formas arcaicas de justiça baseadas nos laços naturais de sangue. Em nenhum momento é colocado em pauta o pecado original, o momento de ruptura que afastou a sociedade de seus protetores. $\mathrm{Ou}$ seja, permanece opaco o referencial capaz de nos oferecer a chave mais funda destes tristes destinos, as coordenadas mais específicas da "crise sacrificial" cuja fenomenologia se desenhou diante de nós.

Em suma, no filme de Ruy Guerra o universo mágico-religioso mostra a sua efetividade mas se mostra um sincretismo sem contorno claro, tal como se verifica no ritual de Sete Vezes onde o sacrifício do animal fica à procura de deuses que o consagrem ou de um preceito comunitário que lhe defina o sentido. Há uma deliberada estranheza neste "teatro da crueldade" feito de forças que atingem diretamente os corpos, deixam marcas, como uma doença. Permeado de grotesco, o filme confia no poder sedutor do abjeto ou no poder de atração da violência repulsiva que deixa entrever um terreno sagrado onde ganham sentido seus banhos de sangue, para além da lógica implacável da economia. Sua alegoria trabalha a ordem simbólica num registro que preserva espaços de enigma e se faz uma fonte de interrogações talvez mais sedutora do que o forte didatismo no tratamento da questão econômica. Tudo se configura como uma espécie de missa negra da história, festival de "violência e tristeza" de um mundo periférico sem lugar para um discurso épico de conquistas ou caminhos de salvação. A justaposição entre passado e presente ressalta realidades que atravessam o tempo, seja a economia onde a migração de mão de obra é dado estrutural, seja a tradição religiosa transportada junto com os 
pobres nos caminhões para as plantações de cacau ou as cidades do sul. Se o tempo presente é observado num relance, apenas na abertura do filme, isto basta para compor a moldura que indica as permanências, deixando claro que o processo de dissolução de todo um esquema de poder não instaurou mudanças substanciais do ponto de vista de quem trabalha e se dirige aos campos de cacau.

Esta condenação implacável da terra tem um aspecto de sonegação total da esperança, dado que separa o filme de Ruy Guerra do de Glauber, também voltado para a força do simbólico no seio da história. Se há melancolia na relação de $O$ Dragão da Maldade com o presente, esta convive com a esperança que se expressa a partir da ponte talvez ainda possível com um mundo arcaico e messiânico cuja fala profética está voltada para o futuro, e mobiliza os mortos (Lampião) para inspirar a revolução. No filme de Ruy Guerra, as figuras que atravessam o tempo "pesam" simplesmente sobre os vivos, exercem influência mágica sobre a sociedade sem que se defina um telos que oriente esta intervenção. Em consonância, é totalmente distinta a "vontade de matar" do cangaceiro de Glauber ou mesmo a de Antonio das Mortes, pois aí tudo gira em torno de um princípio de justiça e de um futuro de salvação cem vezes proclamado.

Em Os Deuses e os Mortos, prevalece a força dos mecanismos que configuram um mundo de danação sobredeterminado: de um lado, a tutela perversa dos deuses (de novo, a lembrar Shakespeare e a imprecação do Rei Lear); de outro, a tutela do Capital que, embora fator de mudança, mostra sua natureza também perversa por trás de toda sua contrastante, porém ilusória, aparência de limpeza. Nesta moldura, o percurso histórico de povo e elite conservadora é de repetição, restando o réquiem para as famílias patriarcais em decadência, palco de uma liturgia da impureza que se cristaliza na figura abjeta de Sete Vidas, corpo onde o Cinema Novo encontra o Cinema Marginal. Sob a inspiração do teatro da crueldade, esta alegoria do desengano em terras periféricas ganha um teor apocalíptico muito próprio a outros filmes daquela virada de década. E a modernização reflexa encontra sua representação, senão a mais radical, sem dúvida a mais agressiva. 


\section{Notas}

1 Ver Ismail Xavier, Alegorias do Subdesenvolvimento: Cinema Novo, Tropicalismo, Cinema Marginal (São Paulo, Brasiliense, 1993).

2 Há aqui, tal como na cena teatral brasileira do período, uma incidência das propostas de Artaud sobre a recuperação agressiva de uma dimensão sagrada da encenação, cena teatral brasileira naquele instante bastante marcada pelo "teatro da Crueldade".

3 René Girad. La Violence et le Sacré, Paris, Editions Bernard Grasset, 1972, capítulo II.

4 Idem, ibidem, p.77.

5 Ver Girard, pp.213-148.

6 Sobre o Grande Mecanismo, ver Jan Kott, Shaskespeare Our Contemporary(New York, W.E. Norton \& Co., 1974). A relação do filme de Ruy Guerra com a dinâmica do Grande Mecanismo nas peças de Shaskespeare é encontrada em Randal Johnson, em Cinema Novo x 5 (Austin, University of Texas Press, 1984), pp. 109-110.

7 Ver Duglas Monteiro, Os Errantes do Novo Século, São Paulo, Duas Cidades, 1974; Maria Isaura Pereira de Queiroz, OMessianismo no Brasil e no Mundo, São Paulo, Dominus, 1965; e Duglas Monteiro, “Um confronto entre Juazeiro, Canudos e Contestado" In O Brasil Republicano: Sociedade e Instituições (1889/1930), São Paulo, Difel, 1977.

8 Ver Randal Johnson, idem, p.108. 